\title{
Upland rice: phenotypic diversity for drought tolerance
}

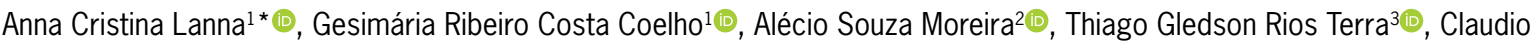 \\ Brondani1 ${ }^{\circledR}$, Gabriel Rios Saraiva ${ }^{4}$, Frederico da Silva Lemos ${ }^{4}$, Paulo Henrique Ramos Guimarães ${ }^{5}$, Odilon Peixoto Morais Júnior ${ }^{5}$, \\ Rosana Pereira Vianello10
}

\author{
${ }^{1}$ Embrapa Arroz e Feijão, Rod. G0-462, km 12, C.P. 179 - \\ 75375-000 - Santo Antônio de Goiás, GO - Brasil. \\ Embrapa Mandioca e Fruticultura, Av. Doutor Ademar Pereira \\ de Barros, 528/529 - 14807-040 - Araraquara, SP - Brasil. \\ 3Universidade Federal do Tocantins - Lab. de Plantas \\ Infestantes, Chácara 69-72, R. Badejos, s/n, Lote 7 - \\ 77404-970 - Gurupi, TO - Brasil. \\ 4Uni-Ahanguera/Centro Universitário de Goiás - Depto. \\ de Ciência Exatas, Biológicas e da Saúde, R. Cândido de \\ Oliveira, 115 - 74423-115 - Goiânia, GO - Brasil. \\ 5Universdiade Federal de Goiás - Depto. de Genética e \\ Melhoramento de Plantas, Rod. G0-462, km 0 - 74001-970 \\ - Goiânia, GO - Brasil. \\ *Corresponding author <anna.lanna@embrapa.br>
}

Edited by: Leonardo Oliveira Medici

Received December 13, 2019

Accepted April 03, 2020

\begin{abstract}
Upland rice is cultivated mostly in Latin America and Africa by small farmers and in areas with risk of dry spells. This study evaluated morphophysiological mechanisms of upland rice associated to drought adaptation. A set of 25 upland rice genotypes were grown in a plant phenotyping platform during 2015 and 2017 under regular irrigation and water restriction. We evaluated morphophysiological traits in shoots (vegetative structures growth, gas exchange, water use efficiency, carboxylation efficiency, water status) and roots (length, surface area, volume and diameter), as well as agronomic traits (grain yield and its components). There was a reduction in grain yield by up to $54 \%$ and $58 \%$ in 2015 and 2017, respectively, under water deficit. Five upland rice genotypes with the best yield performances in both water treatments applied were recommended to the upland rice-breeding program: Bico Ganga, BRS Esmeralda, BRSMG Curinga, Guarani, and Rabo de Burro. In this study, morphophysiological traits associated to drought tolerance concerned the plant high capacity to save water in the leaves, low leaf water potential, high ability to reduce vegetative structures, high water use efficiency, high photosynthetic capacity, and improved capacity to absorb water from drying soil, either by osmotic adjustment or additional investment into the root system. Therefore, we concluded that different secondary traits contributed to drought tolerance and should be evaluated along with grain yield to improve efficiency of breeding selection.
\end{abstract}

Keywords: grain yield, gas exchange, water status, root system, vegetative morphology

\section{Introduction}

Rice (Oryza sativa L.) is essential for food security for more than half of the world's population (Jumaa et al., 2019). Since rice has an evolutionary peculiarity of semiaquatic, flooded rice paddies have become the major form of cultivation, growing in irrigated and rainfed lowland conditions, equivalent to $75 \%$ and $19 \%$ of the global production area, respectively (Kikuta et al., 2016). Increasing grain yield of irrigated areas is not enough to supply future demand for rice; furthermore, expansion of production areas is restricted, due to the water scarcity (Parthasarathi et al., 2012). Upland rice represents $4 \%$ of the global rice production and is grown less than $9 \%$ of total rice acreage in Asia, $46 \%$ in Latin America, and $47 \%$ in West Africa (Kikuta et al., 2016). According to Singh et al. (2014), upland rice accounts for $84 \%$ of the total area in Sub-Saharan Africa and it is cultivated mostly by smallholder farms with an average area smaller than 0.5 ha. On the other hand, in Latin America, upland rice is cultivated in large-areas of mechanized harvesting (Bernier et al., 2008).

Drought is one of the most severe abiotic stresses limiting rice yield worldwide and poses a serious threat to rice sustainability in rainfed agriculture $(\mathrm{Wu}$ and Cheng, 2014). According to Heinemann et al. (2015), rice yield in upland cultivation (tropical regions mainly) has its yield potential reduced by up to $35 \%$ due to drought-stress conditions.

Reduction in water availability for plants results in a complex response characterized by a decrease in the water potential of its tissues, leading to several changes in different plant processes (Rosales et al., 2012). Some processes reported for upland rice are (a) appropriate phenological patterns that combine crop growth and the amount of water available in the soil (water environment), (b) deep root system, (c) thick stems and reduced number of stomata, (d) osmotic adjustment to maintain cell homeostasis and, consequently, avoid a rapid decrease in leaf-water potential, and (e) senescence delay, also known as stay-green trait, which allows the maintenance of the photosynthetic capacity and the photoassimilate remobilization for a longer time period (Fukai and Cooper, 1995; Boonjung and Fukai, 1996).

Thus, the establishment of sustainable crop systems of upland rice requires better understand of changes in the morphophysiological mechanisms, contributing to drought tolerance and yield effects. This study aimed to (a) identify a series of morphophysiological and agronomic traits related to drought tolerance in upland rice genotypes of Embrapa Core Collection under greenhouse cultivation, and (b) characterize morphophysiological components to be used as indicators for drought tolerance for plant breeding processes.

\section{Materials and Methods}

\section{Germplasm}

We used 25 accessions of upland rice (Oryza sativa L.) with different responses to drought, obtained 
through previous field experiments (Bueno et al., 2012). The accessions were represented by 16 landraces, six commercial cultivars from the Embrapa rice-breeding program and three international lines from France and
Africa (Table 1). The genotypes were categorized in five phenological groups based on days for the beginning of the reproductive stage (R2 - collar formation on flag leaf/ R3 - panicle exsertion) (Counce et al., 2000).

Table 1 - Information on 25 upland rice (Oryza sativa L.) genotypes, categorized into five phenological groups, in both years of trials, 2015 and 2017: genotype identification (ID), code, subspecies, R2/R3 and R8/R9 reproductive stages (DAE, days after emergence), germplasm type, origin, and water deficit period.

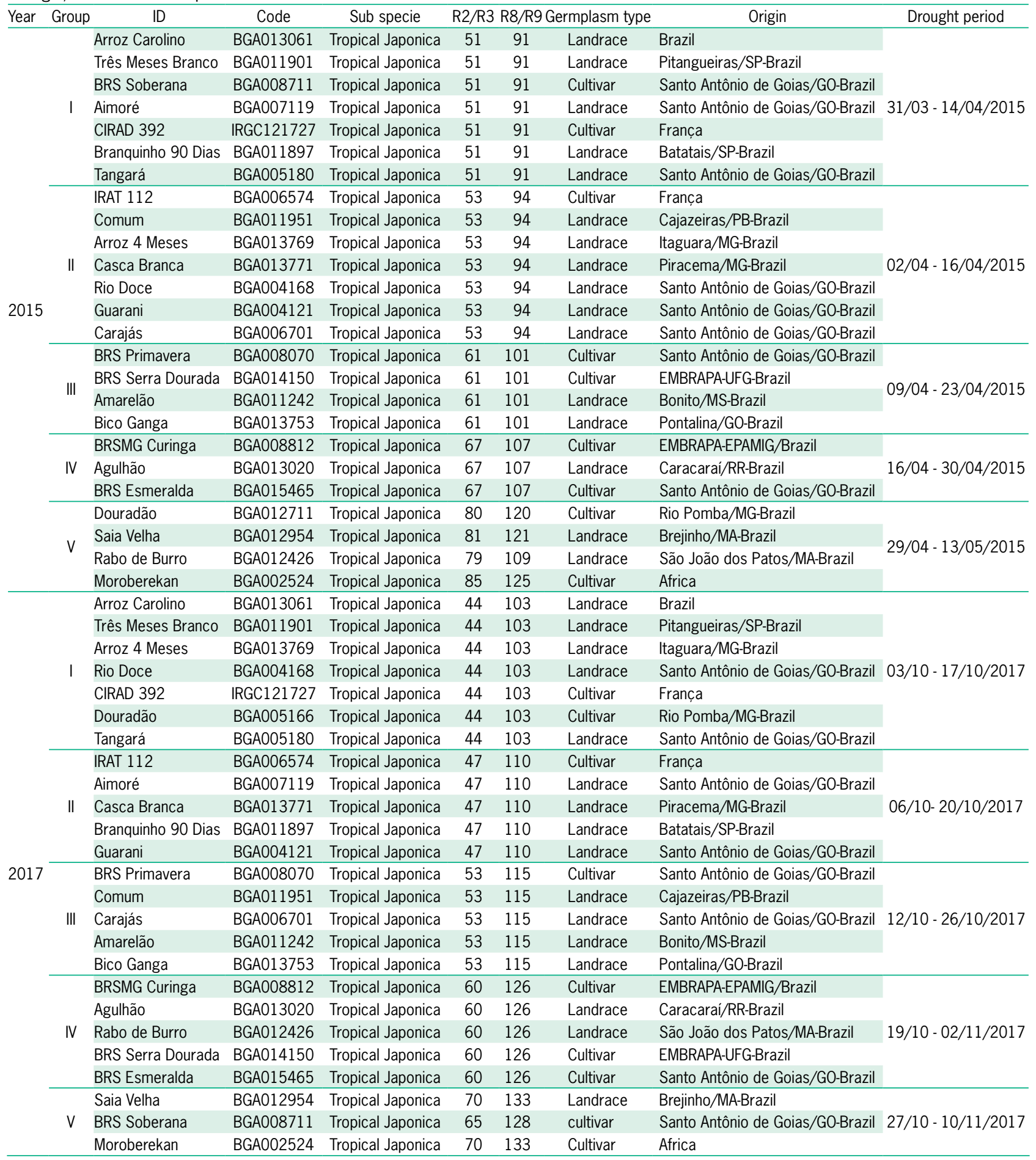




\section{Experimental conditions}

The experiments were carried out under a greenhouse condition at the plant phenotyping platform facility the Integrated System for Drought-Induced Treatment (Portuguese acronym SITIS) from Feb to June 2015, and from Aug 2017 to Jan 2018, 16²8'00" S, $49^{\circ} 17^{\prime} 00^{\prime \prime} \mathrm{W}$, altitude of $823 \mathrm{~m}$. At the facility, 384 soil columns (diameter: $25 \mathrm{~cm}$; height: $100 \mathrm{~cm}$ ) were placed on a digital scale to monitor the water amount in each column. The soil, characterized as red latosol (Oxisol), was sieved through $125 \mathrm{~mm}$ mesh to remove larger aggregates and it was enriched with minerals, including $1.125 \mathrm{~g} \mathrm{~kg}^{-1}$ of 5-30-15 formulation, and $0.250 \mathrm{~g} \mathrm{~kg}^{-1}$ of ammonium sulfate after germination. Urea was applied at the beginning of tillering (V4-V5 stage; $0.350 \mathrm{~g} \mathrm{~kg}^{-1}$ ) and in the panicle differentiation (R1 stage; $0.150 \mathrm{~g} \mathrm{~kg}^{-1}$ ), four days before the period of water restriction.

The treatments consisted of combinations of two water levels including normal watering (control treatment) and restriction water (stress treatment) conditions. In the control treatment, the amount of soil water was equivalent to $80 \%-85 \%$ of field capacity (FC) established and kept throughout the crop cycle. For the stress treatment, irrigation was performed until the plant reached the reproductive stage (R2/R3), followed by suspension of irrigation for five days, with subsequent replacement of only $50 \%$ of evapotranspirated water at the plate placed on the column bottom for 10 days. The amount of evapotranspirated water was estimated based on the water quantity required to keep soil FC at $80 \%-85 \%$ in the control treatment. Water stress was kept until the control plants reached R6 (grain depth expansion) / R7 (grain dry down) stage. After this period, irrigation was restored until the end of the crop cycle, R8 (at least one grain on the main stem panicle with a brown hull) / R9 (all grains that reached R6 have brown hulls). In the control columns, the evapotranspiration rate was determined daily (difference between the reference mass and the column/day mass) and restored through irrigation placed on the soil surface to achieve the initial mass (reference mass) again. Each column contained three plants.

\section{Agronomic and morphophysiological measurements}

\section{Grain yield and yield components}

The agronomic traits evaluated were grain yield (GY - g column ${ }^{-1}$, which means the total mass of grains, in grams, obtained for three plants per column) and its components, such as the number of filled grains (NFG, filled grains average in six panicle column ${ }^{-1}$, number of empty grains (NEG, empty grains average in six panicle column ${ }^{-1}$ ), and 100-grain mass (100GM, g). The last variable was evaluated in 2015. Spikelet sterility was estimated as SS $=(\mathrm{NEG} \times 100) \mathrm{TG}^{-1}$, where $\mathrm{SS}=$ spikelet sterility, NEG = number of empty grains, and $\mathrm{TG}=$ total number of grains.

\section{Shoot growth}

The following assessments were made for shoot (vegetative structures) growth and reproductive organs traits: (a) leaf area $\left(\mathrm{LA}, \mathrm{cm}^{2}\right)$, average of two flag-leaf of two plants in column, using LI-COR leaf area meter; (b) plant height $(\mathrm{PH}, \mathrm{cm})$; (c) tiller number (TN, units); (d) panicle length $(\mathrm{PL}, \mathrm{cm})$; (e) shoot dry matter biomass (SDMB, g), through drying samples at $65{ }^{\circ} \mathrm{C}$ until a constant weight was achieved and (f) panicle number (PN, units). Data on $\mathrm{PH}, \mathrm{TN}, \mathrm{SDMB}$, and PN were the average of three plants in the column. Additionally, LA and TN were measured on the last day of water restriction. The $\mathrm{PH}, \mathrm{PL}, \mathrm{SDMB}$, and $\mathrm{PN}$ were obtained at harvesting time. LA and PL were measured in 2015.

\section{Root phenotyping}

The root system was evaluated according to the methodology described by Lanna et al. (2016). Briefly, to carry out the root system capture, acrylic tubes were installed inside the columns and three rice plants were planted around the tube. The root system growth was assessed by measuring length $(\mathrm{cm})$, surface area $\left(\mathrm{cm}^{2}\right)$, volume $\left(\mathrm{cm}^{3}\right)$ and diameter $(\mathrm{mm})$ of the roots through images generated by CI - 600 root scanner, with quantification by the WinRhizo software. Root images corresponding to depth 1 ( 5 to $25 \mathrm{~cm}$ ) and $2(25$ to $45 \mathrm{~cm})$ were taken on the $1^{\text {st }}$ day after irrigation cut-off (phase I), $5^{\text {th }}$ day after irrigation cut-off (phase II) and $10^{\text {th }}$ day after the plants received $50 \%$ of water at the column base (phase III). These parameters were evaluated in 2017.

\section{Gas exchange}

Gas exchange rates were taken on flag leaves of two plants in each column and measurements were made using a portable gas exchange analyzer in the infrared region (LCpro + ). The parameters measured were: photosynthetic rate $\left(A, \mu \mathrm{mol} \mathrm{CO} \mathrm{CO}^{-2} \mathrm{~s}^{-1}\right)$, transpiration

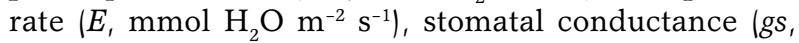
mol $\left.\mathrm{H}_{2} \mathrm{O} \mathrm{m}^{-2} \mathrm{~s}^{-1}\right)$, and internal $\mathrm{CO}_{2}$ concentration $\mid C i$, $\left.\mu \mathrm{mol} \mathrm{mol}^{-1}\right)$. The equipment was set to use temperature and concentrations of $370-400 \mathrm{~mol} \mathrm{~mol}^{-1} \mathrm{CO}_{2}$ in the air, the reference condition used in the IRGA phothosynthesis chamber. The photon flux density photosynthetic active (PPFD) used was $1200 \mu \mathrm{mol}$ [quanta] $\mathrm{m}^{-2} \mathrm{~s}^{-1}$. The minimum equilibration time set for performing the reading was $2 \mathrm{~min}$. Measurements in both control and stressed plants were carried out at from $07 \mathrm{~h} 30$ to $11 \mathrm{~h} 00$ a.m. on three evaluation dates during the water deficit period. These dates included the $1^{\text {st }}$ day after irrigation cut-off (phase I), $5^{\text {th }}$ day after irrigation cut-off (phase II), and $10^{\text {th }}$ day after the plants received $50 \%$ of water at the column base (phase III). Water use efficiency $\left(W U E_{\llcorner} \mu \mathrm{mol} \mathrm{CO} \mathrm{mol}^{-1} \mathrm{H}_{2} \mathrm{O}\right)$ was calculated as the ratio between $A$ and gs (Rosales et al., 2012). Carboxylation efficiency $\left(C E,\left(\mu \mathrm{mol} \mathrm{m} \mathrm{m}^{-2} \mathrm{~s}^{-1}\right)\right.$ $\left.(\mu \mathrm{mol} \mathrm{mol})^{-1}\right)$ was expressed as the ratio between $A$ and $C i$ (Silva et al., 2013). 


\section{Water status}

Leaf water potential $\left(\Psi_{\mathrm{w}}\right)$ was evaluated between 05h00 and 06h00 a.m. using a Scholander pressure chamber (Scholander et al., 1965). The reading was determined at the extremity (tip) of two flag leaves of the primary tiller of two upland rice plants at the end of the water restriction period. Pressure was applied until exudation from the cut made in the leaf collar. Leaf relative water content (RWC, \%), osmotic potential ( $\Psi \mathrm{s}, \mathrm{MPa})$, and osmotic adjustment $(\mathrm{OA} ; \mathrm{MPa})$ were also determined according to the methodology described by Bajji et al., 2001. These parameters were evaluated in 2015.

\section{Experimental design and statistical analysis}

All 25 genotypes were evaluated in a $5 \times 5$ lattice design with 12 repetitions: six repetitions (columns) were for irrigated conditions, and other six repetitions were used for the water deficit treatment, totaling 300 experimental units (with each column containing three plants). Among the six repetitions per water treatment, three repetitions were used for destructive (LA, $\Psi_{\mathrm{w}}$, RWC, $\Psi_{\mathrm{s}}$ and OA; only in 2015) and three for non-destructive measurements (gas exchange, shoot structure, grain yield and its components). For all measurements of shoot traits, transformation $\sqrt{ } \mathrm{x}+1.0$ was applied (where x represents the analyzed variables), which is often used for measurable or count data for normalizing and reducing data skewness (Shapiro and Wilk, 1965, normality test $5 \%$ ). The transformed data were subjected to the analysis of variance (ANOVA) based on a fixed linear model and to the joint analysis within each year (2015 and 2017), considering the following: blocks effects, two water levels effects, 25 genotypes, and water level $\times$ genotype interaction. The treatment means were compared by the Scott-Knott test $(p<0.05)$, due to a large number of treatments used in this study, which facilitated the ranking of 25 genotypes into homogeneous groups, without ambiguity. These analyses were carried out using the $\mathrm{R}$ platform (R Core Team, 2018). For the root traits, the data were analyzed by the GENES statistical analysis software. The joint analysis of variance was performed between the environments (irrigated and stressed) for each depth, and the significant differences were tested by the Tukey test at $p<0.05$.

\section{Results and Discussion}

In crops, such as upland rice, where seeds are the product of interest, the main criteria for selecting agronomical tolerance to drought are the traits that lead to higher grain yield. In this study, the analysis of grain yield showed a significant difference $(p<0.05)$ for all variation sources. For 2015 and 2017, the genotypes accounted for $41 \%$ and $50 \%$ of the total sum of squares, while the environment (water level) accounted for $41 \%$ and $44 \%$ and the genotype versus environment interaction accounted for $18 \%$ and $7 \%$, respectively. The agronomic performance (grain yield) of genotypes cultivated under two water treatments in 2015 and 2017 is shown in Figures 1A and 1B. In 2015, Bico Ganga, BRS Esmeralda, BRSGO Serra Dourada, BRSMG Curinga, Casca Branca, Guarani, Rabo de Burro, Rio Doce, and Três Meses Branco showed better yield under drought (average grain yield $70.9 \mathrm{~g} \mathrm{column}^{-1}$ ) and irrigated (average grain yield $119.8 \mathrm{~g} \mathrm{column}^{-1}$ ) conditions. In 2017, Agulhão, Bico Ganga, BRS Esmeralda, BRS Primavera, BRS Soberana, BRSMG Curinga, Guarani, and Rabo de Burro were more productive under drought (average grain yield $40.90 \mathrm{~g} \mathrm{column}^{-1}$ ) and irrigated (average grain yield $63.98 \mathrm{~g} \mathrm{column}^{-1}$ ) conditions. Among the upland rice genotypes evaluated, Bico Ganga, BRS Esmeralda, BRSMG Curinga, Guarani, and Rabo de Burro showed better agronomic performance at both water levels in both two years of trials and were then ranked as top genotypes. These genotypes probably
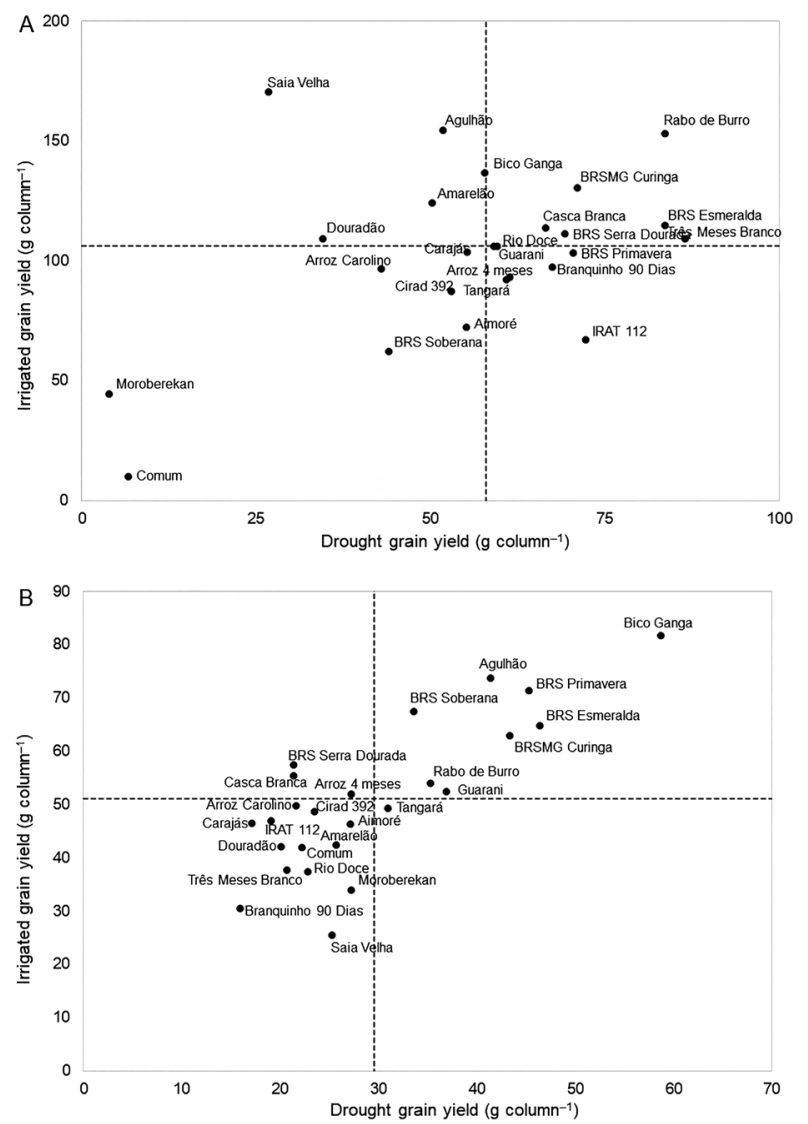

Figure 1 - Grain yield of upland rice (Oryza sativa L.) cultivated in SITIS Platform in years 2015 (A) and 2017 (B). The dotted lines define the average value of grain yield under irrigated and drought conditions. Genotypes that showed higher yield under irrigated and drought conditions were identified in the upper right-hand quadrant in Figures A and B. Bico Ganga, BRS Esmeralda, BRSMG Curinga, Guarani, and Rabo de Burro stood out in both years of trials. 
present favorable alleles of drought tolerance that may be useful in breeding programs of upland rice. Two of these genotypes are modern cultivars (BRS Esmeralda and BRSMG Curinga), which could be qualified as parents in breeding programs of upland rice. For yield components, the average number of filled-grains and empty-grains was 138 and 46 in 2015, and 266 and 82 in 2017, respectively, in rice cultivated under irrigated condition (Table 2). For plants under drought, the total number of filled-grains and empty-grains were 99 and 37 in 2015, and 184 and 73 in 2017, respectively. The average value of 100-grain weight was $3.03 \mathrm{~g}$ under irrigated condition and $2.62 \mathrm{~g}$ under stress, determined only in 2015. IRAT $112(41 \%)$ and Douradão (52\%) presented the highest percentage of spikelet sterility under irrigated condition, and Moroberekan (94\%) and Branquinho 90 Dias (73 \%) under drought condition in 2015 and 2017, respectively. In both years of trials, environmental conditions of phenotyping platform SITIS were severe. Particularly in 2017 , in addition to artificially imposed water stress, the maximum temperature of $44.7^{\circ} \mathrm{C}$ was $6.7^{\circ} \mathrm{C}$ higher than the conditions of the 2015 trial, during the water deficit period. In addition, the minimum relative humidity of $26 \%$ was $42 \%$ lower than that of the 2015 trial (Table 3). According to Choudhary et al. (2018), drought commonly occurs combined with other environmental stresses, such as excessive light incidence, heat, and low relative humidity, and characterizes multiplicity of stresses in the tropics. For rice, along with drought, high temperature (up to $33.5^{\circ} \mathrm{C}$ ) contributed to yield reduction due to the shortening of the vegetative period and high spikelet sterility (Peng et al., 1995; Matsui et al., 1997; Shah et al., 2011).

According to Bernier et al. (2008), practices based on the assessment of agronomic performance of crop species require a long procedure, which limits breeding efficiency. Thus, a better understand of mechanisms of drought tolerance is necessary, since the association between main (grain yield and its components) and secondary (morphophysiology) traits could provide greater selection efficiency. For this, identifying morphophysiological traits related to drought tolerance is relevant to assist in the identification of mechanisms underlying these adaptation processes and thus in the selection of tolerant genotypes. In this study, upland rice plants reacted to drought stress by slowing down their growth (Table 4). In 2015, most genotypes (Agulhão, Aimoré, Amarelão, Arroz 4 meses, Bico Ganga, BRS Esmeralda, Primavera, BRSMG Curinga, Carajás, Casca Branca, Cirad 392, Douradão, Guarani, Moroberekan, Rabo de Burro, Rio Doce, Tangará, and Três Meses Branco) showed reduced $\mathrm{PH}$ (14\% on average) under drought condition. While, in 2017, only six genotypes (Agulhão, Bico Ganga, BRS Serra Dourada, Carajás, Rabo de Burro, and Rio Doce) presented an average reduction of $12 \%$. Overall, there was no difference between plants grown under both water levels for SDMB, TN, and PN, in both years of trials. Parameters
LA and PL, taken in 2015, showed reductions of $13 \%$ and $3 \%$. LA and $\mathrm{PH}$ were the main morphological traits affected by drought stress in top genotypes Bico Ganga, BRS Esmeralda, BRSMG Curinga, Guarani, and Rabo de Burro, in both years of trials. According to Fischer et al. (2003) and Chaves et al. (2009), reduction of leaf growth and stem elongation in rice plants are the first processes affected by drought and could be considered as a tolerance mechanism, since they reduce the transpiration capacity, and consequently, plant demand for water. Furthermore, slowed growth /due to reduction of stomatal conductance, $\mathrm{CO}_{2}$ assimilation and, consequently, photoassimilates production and accumulation) has been suggested as an adaptive trait for plant survival under stress. This trait allows plants to divert assimilates and energy into protective molecules to deal with stress $(\mathrm{Zhu}, 2002)$ and/or keep root growth by increasing water acquisition (Chaves et al., 2003; Pandey and Shukla, 2015).

The effect of the drought treatment was also evaluated by characterization of the root system, an important organ to increase rice yield under water stress (Pandey and Shukla, 2015; Kundur et al., 2015). According to Kato et al. (2006), rice root is complex, combining various root morphologies and showing considerable genotypic variation, also subjected to environmental effects. Thereby, a deep root system could improve adaptation of upland rice during drought by increasing capacity of extraction water, keeping high leaf water status with better crop performance under drought conditions (Kamoshita et al., 2004; Mishra and Salokhe, 2011). In this study, the analysis of the root system of upland rice showed a significant difference $(p<0.05)$ for most variation sources. At depth 1 (5-25 $\mathrm{cm})$, the genotypes accounted for $14 \%$ of the total sum of squares, the environment (water level) accounted for $54 \%$, and the double interaction, genotype versus water lever, accounted for $32 \%$. At depth $2(25-45 \mathrm{~cm})$, the genotypes accounted for $62 \%$ of the total sum of the square, the environment (water level) accounted for $20 \%$, and the double interaction, genotype versus water level, accounted for $17 \%$.

The root system properties (length, surface area, volume, and diameter) of upland rice plants during the drought period are shown in Figure 2. Under irrigated condition, the genotypes that stood out mostly in terms of length, area, volume, and root diameter were IRAT 112, Agulhão, BRSMG Curinga (top genotype), Comum, Rabo de Burro (top genotype), and Saia Velha, at both depths. Under drought condition, the highlight was BRSMG Curinga followed by Agulhão, Comum, Rabo de Burro, and Saia Velha. Therefore, among top genotypes, BRSMG Curinga, and Rabo de Burro presented greater robustness of the root system, mainly at depth 2 (25 $45 \mathrm{~cm})$, irrespective of the water level applied. This is in accordance with Pandey and Shukla (2015), which describe that under water deficit, root growth is usually kept, while shoot growth is inhibited. Conversely, Ji et 


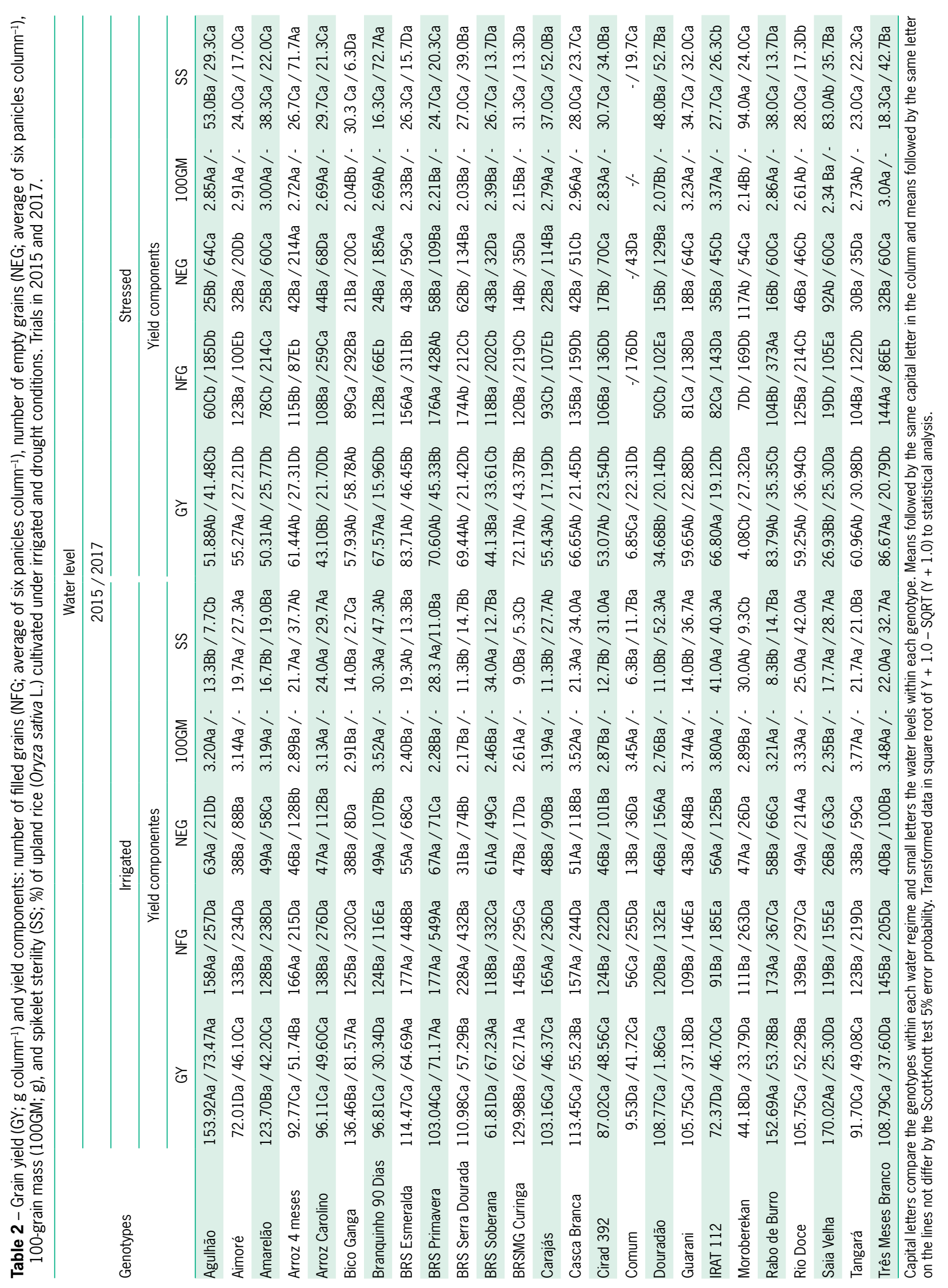


Table 3 - Climatic variables on the phenotyping platform SITIS on growth of upland rice (Oryza sativa L.), including temperature and relative humidity, maximum and minimum values. Upland rice (A and C) and drought period (B and D), in 2015 and 2017.

\begin{tabular}{|c|c|c|c|c|}
\hline Climatic condition & $\mathrm{T} \max$ & $T \min$ & $\mathrm{RH} \max$ & $\mathrm{RH}$ min \\
\hline & \multicolumn{2}{|c|}{${ }^{\circ} \mathrm{C}-$} & \multicolumn{2}{|c|}{$-\%$} \\
\hline & \multicolumn{4}{|c|}{2015} \\
\hline Upland rice cycle ${ }^{A}$ & 37.5 & 21.5 & 81.3 & 40.9 \\
\hline \multirow[t]{2}{*}{ Drought period ${ }^{\mathrm{B}}$} & 38.0 & 22.4 & 84.3 & 44.6 \\
\hline & \multicolumn{4}{|c|}{2017} \\
\hline Upland rice cycle ${ }^{c}$ & 43.4 & 22.1 & 66.9 & 27.6 \\
\hline Drought period ${ }^{D}$ & 44.7 & 23.3 & 62.7 & 26.0 \\
\hline
\end{tabular}

A02 Feb to 15 June, 2015; B31 Mar to 13 May, 2015; '21 Aug, 2017 to 19 Jan, 2018; D03 Oct to 10 Nov, 2017. al. (2012) found a more extensive deeper root growth in a tolerant rice cultivar, IRAT109, after 20 days of irrigation cut-off. The findings of our study indicate a mechanism at the molecular level underlying a constitutive root growth for the root traits evaluated. Water deficit is an important environmental constraint and influences all physiological processes in plant growth, affecting gas exchange mechanisms (Ma et al., 2018).

The stress effects on $A, E, g s, C i, W U E$, and $C E$ in upland rice plants are shown in Table 5. During phase I, where control and stress columns were in similar conditions of soil water availability, there was genetic variability among rice accessions, implying a contrast for the gas exchange traits evaluated, in both years of
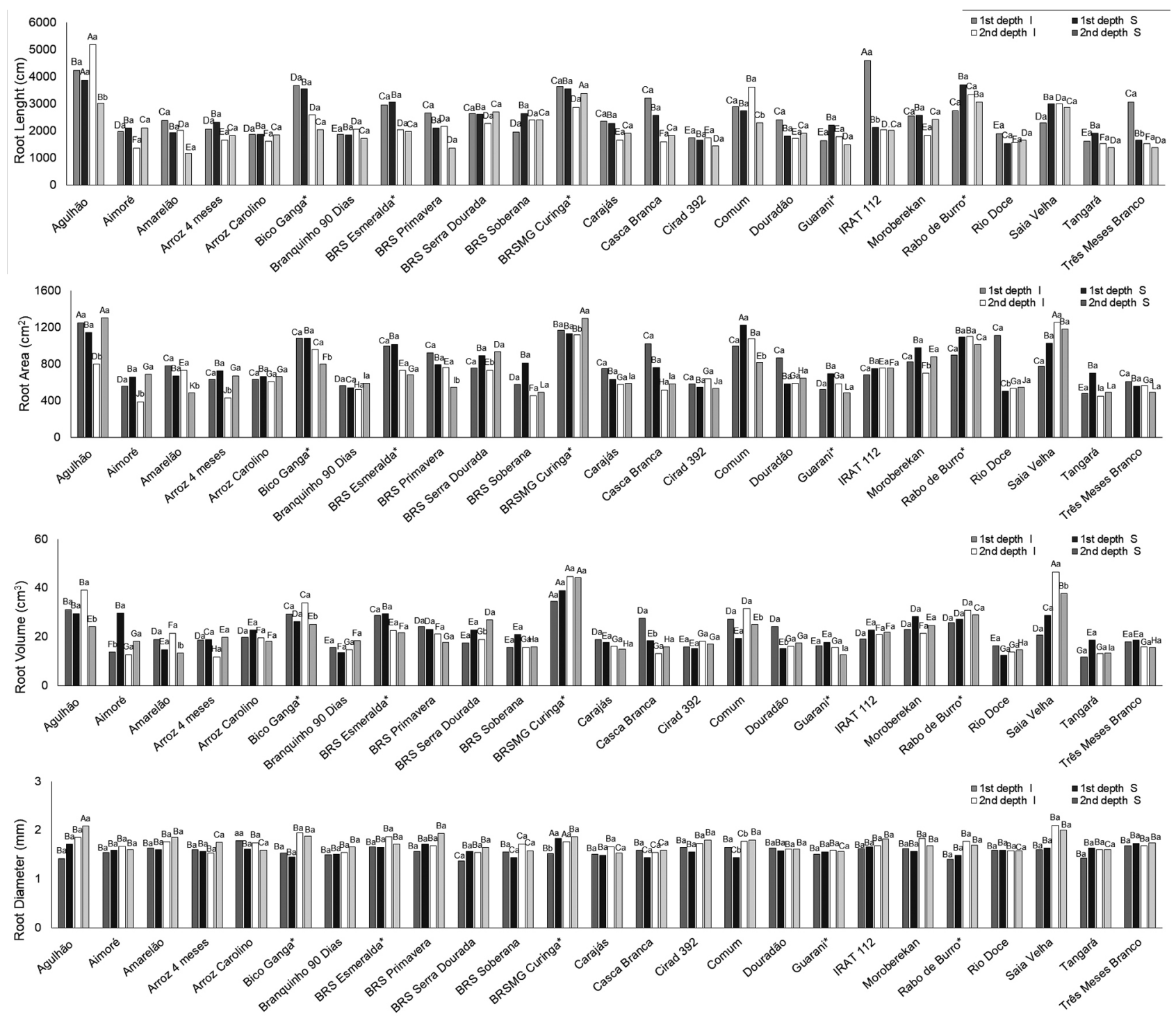

Figure 2 - Root length $(\mathrm{cm})$, Root area $\left(\mathrm{cm}^{2}\right)$, Root volume $\left(\mathrm{cm}^{3}\right)$, and Root diameter $(\mathrm{mm})$, at first (soil layer of 5 - $25 \mathrm{~cm}$ ) and second (soil layer of $25-45 \mathrm{~cm}$ ) depths of the soil cultivated with upland rice (Oryza sativa L.). Plants were grown under irrigated and drought conditions. Capital letters compare genotypes within each water regime and small letters compare water regimes within each genotype. Means followed by the same letter do not differ by the Tukey test $5 \%$ error probability. Parameters were evaluated in 2017. 


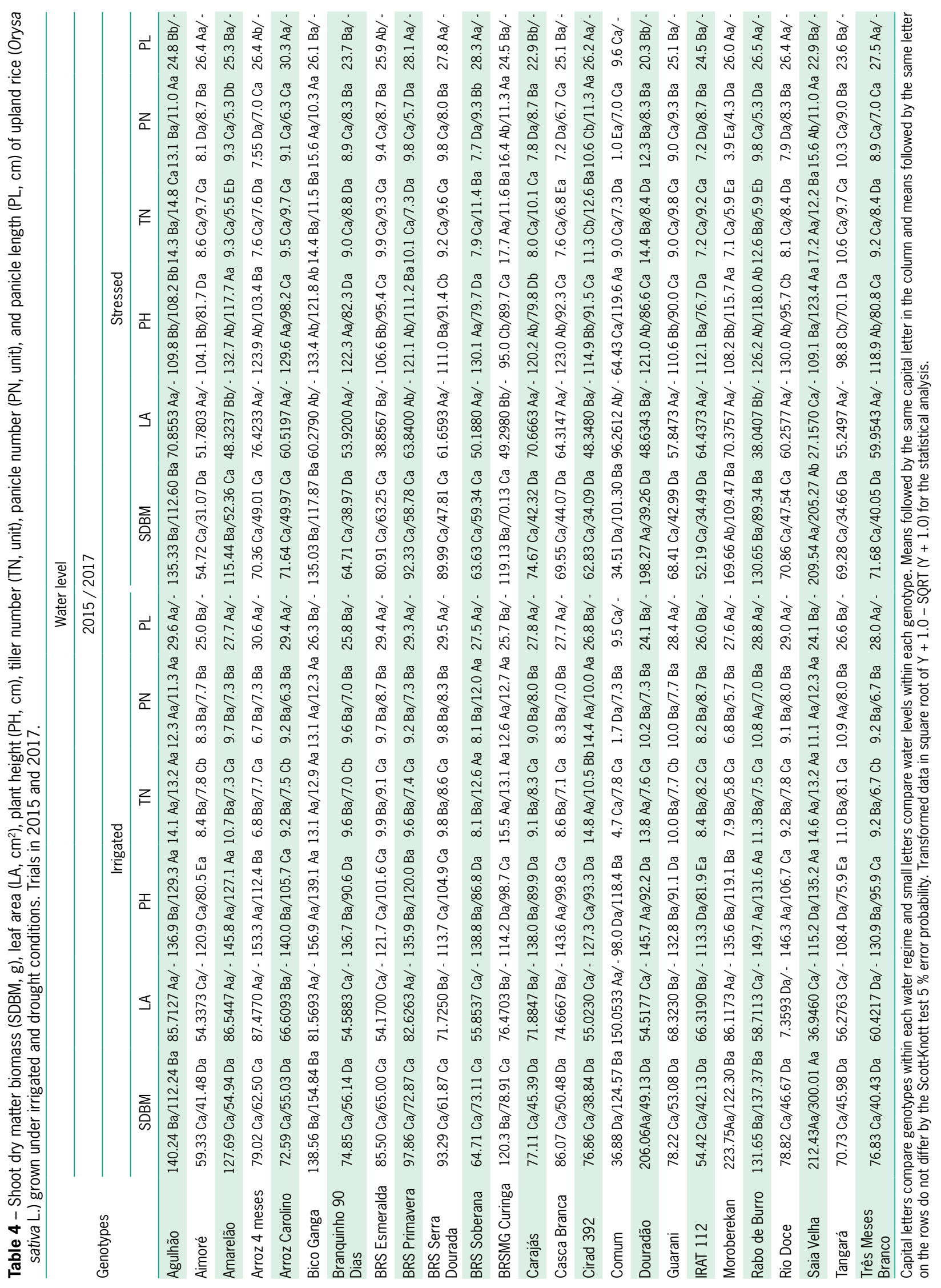




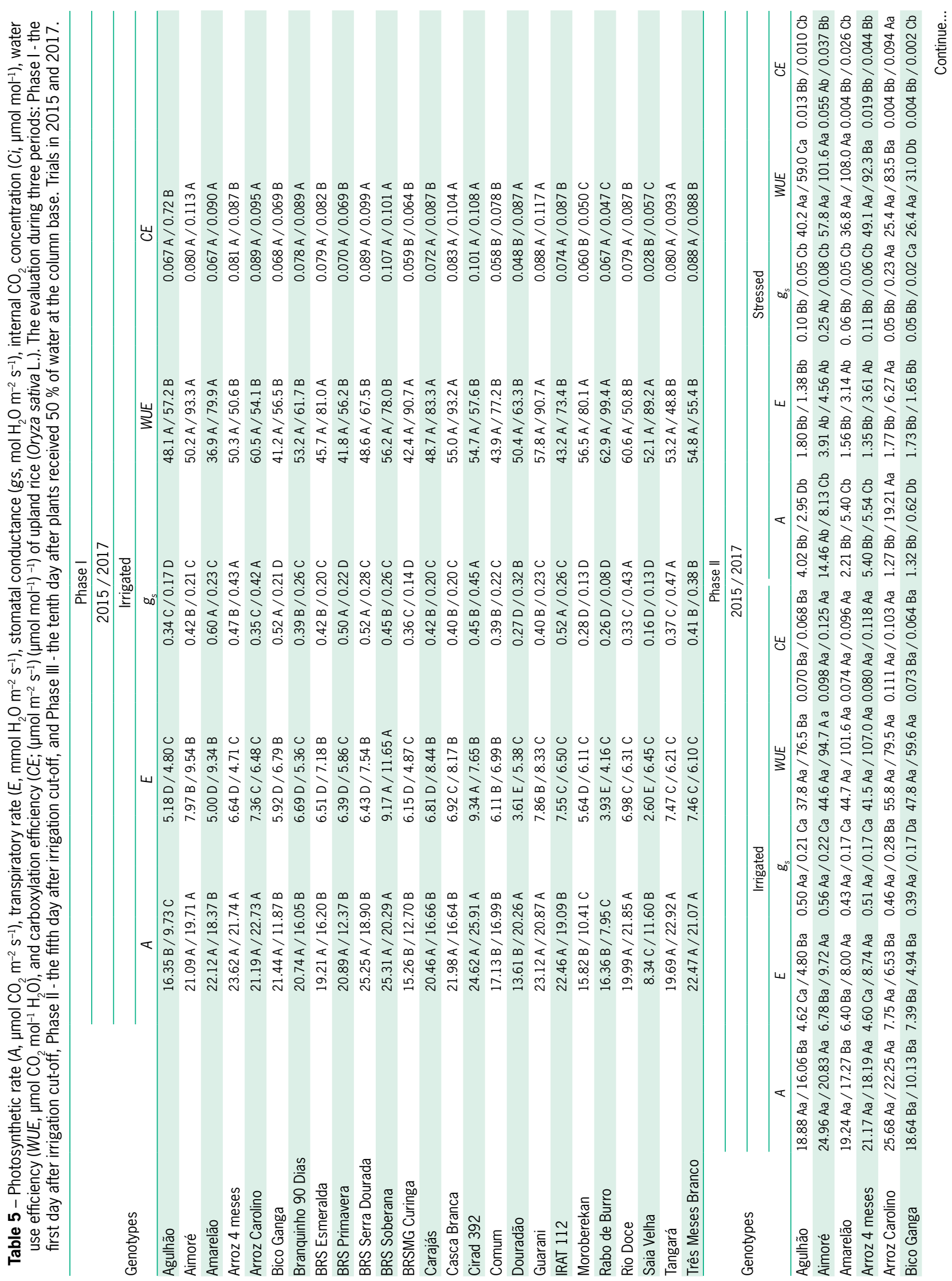




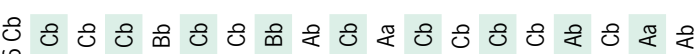

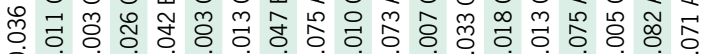
0.00000000000000000

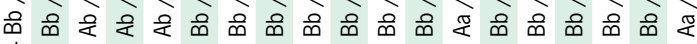

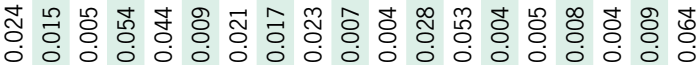

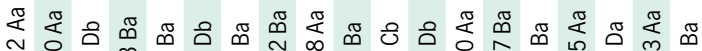

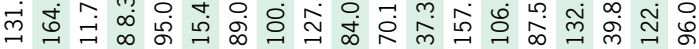

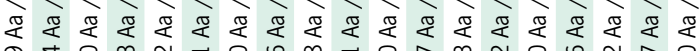

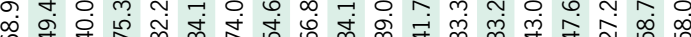

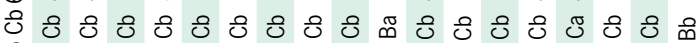

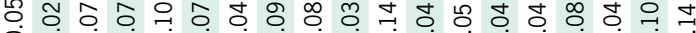

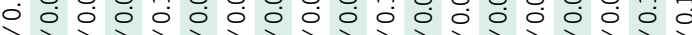

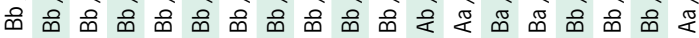

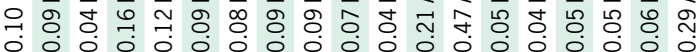
으

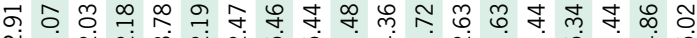

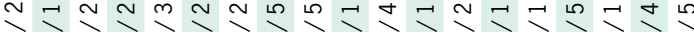

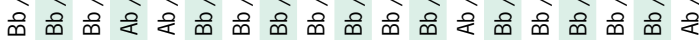

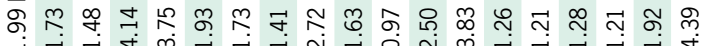

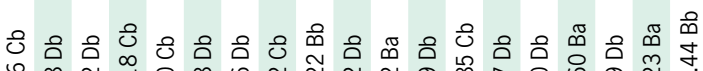

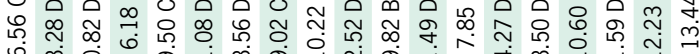

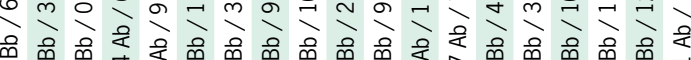
ه ن +

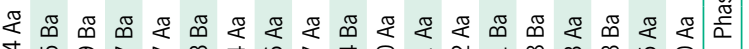

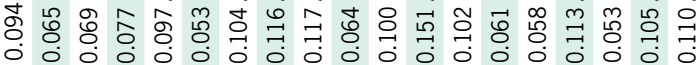

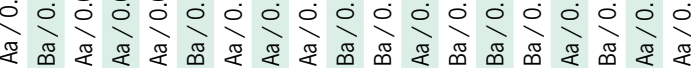

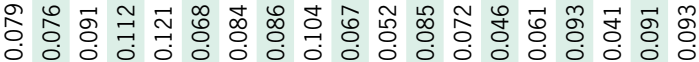

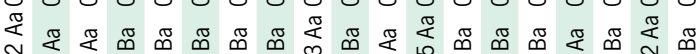
家 亏̆ं

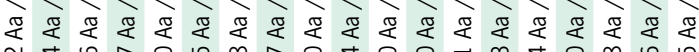

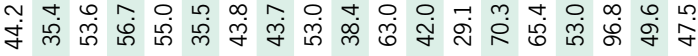

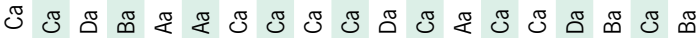

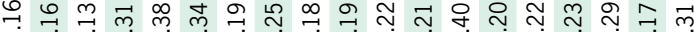

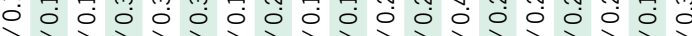

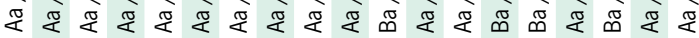

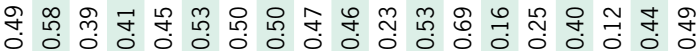
๓ீ

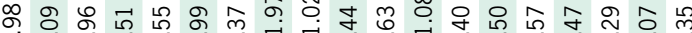

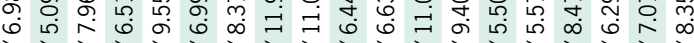

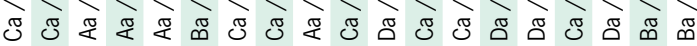

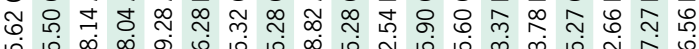

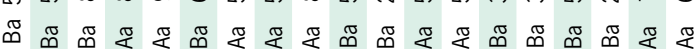
임 ப்

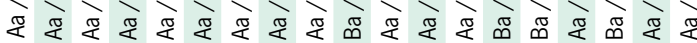

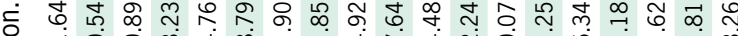

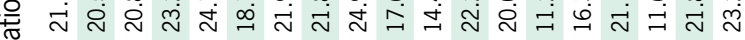

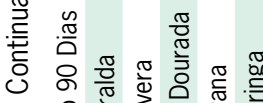

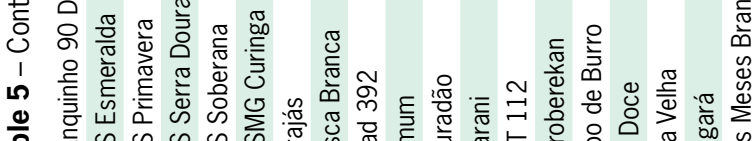

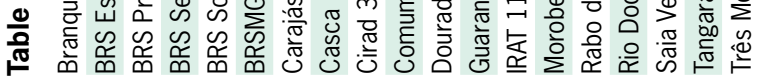

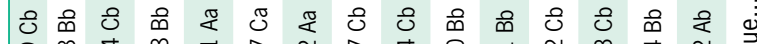

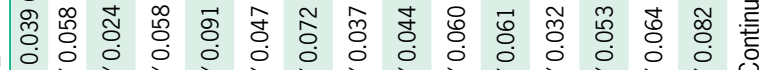

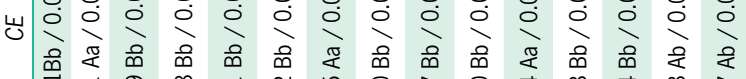

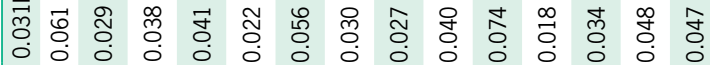

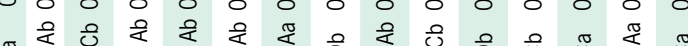

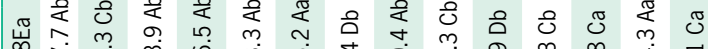
山س

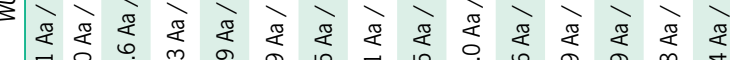
点

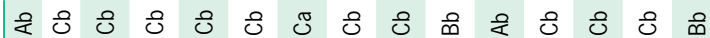

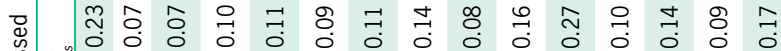
总

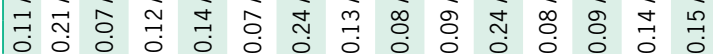
중 ป ₹

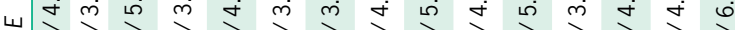

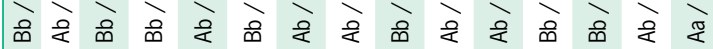

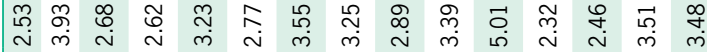

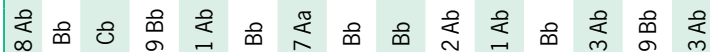

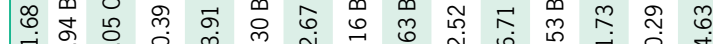
४ $\exists$ i

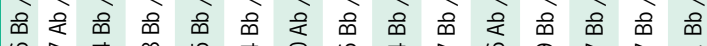

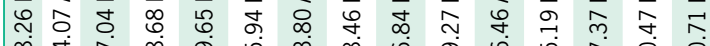
空 $\infty$ I $\wedge$ o

ฮల

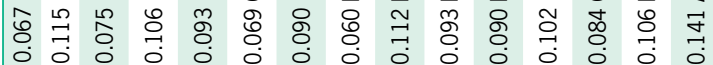

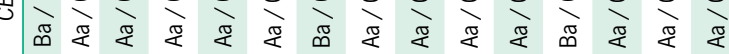

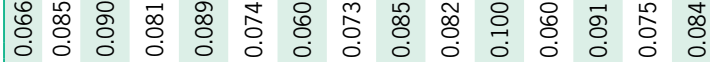
芯恕芯

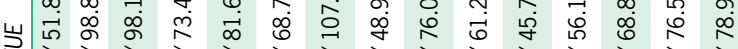

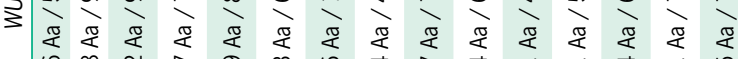

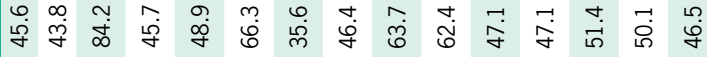
లீ வீ

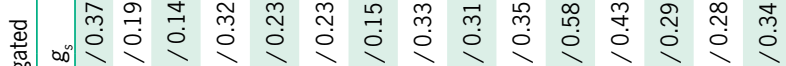

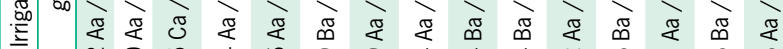
苟员

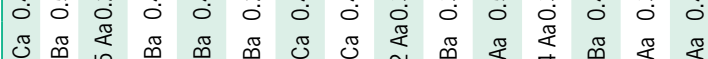
㲅 त̂

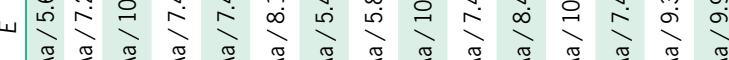
న

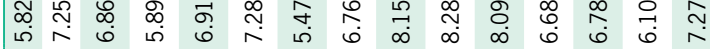
汇

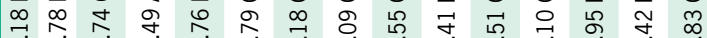

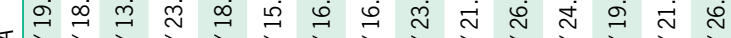

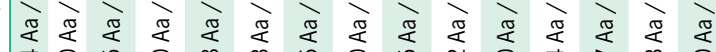
J

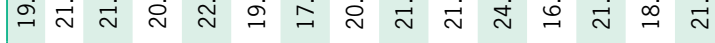

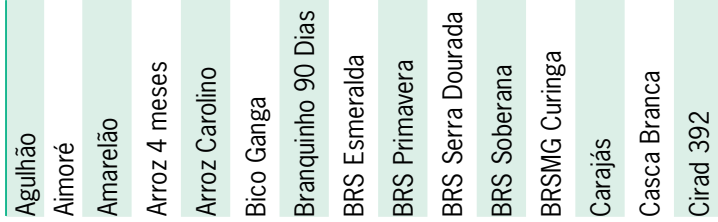




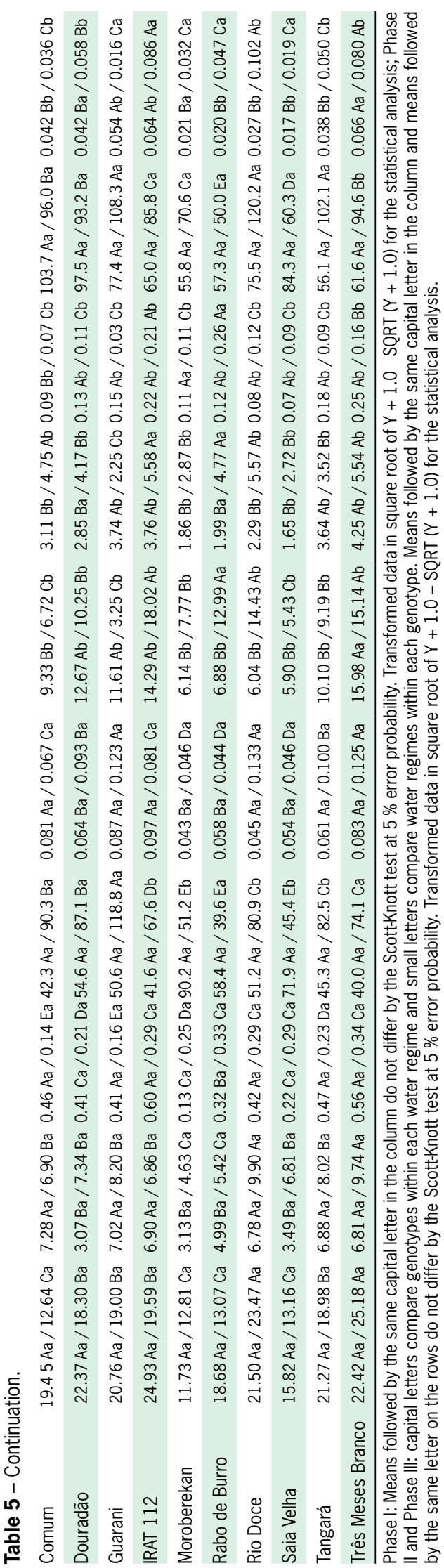

trials. In 2015, $A$ ranged from 8.34 to $25.31 \mu \mathrm{mol} \mathrm{CO}_{2}$ $\mathrm{m}^{-2} \mathrm{~s}^{-1}, E$ ranged from 2.60 to $9.34 \mathrm{mmol} \mathrm{H}_{2} \mathrm{O} \mathrm{m}^{-2} \mathrm{~s}^{-1}$, and $g s$ (number and activity of stomata) ranged from 0.16 to $0.52 \mathrm{~mol} \mathrm{H}_{2} \mathrm{O} \mathrm{m}^{-2} \mathrm{~s}^{-1}$. In 2017, 7.95 to $25.91 \mu \mathrm{mol}$ $\mathrm{CO}_{2} \mathrm{~m}^{-2} \mathrm{~s}^{-1}, 4.16$ to $11.65 \mathrm{mmol} \mathrm{H}_{2} \mathrm{O} \mathrm{m}^{-2} \mathrm{~s}^{-1}$, and 0.13 to $0.47 \mathrm{~mol} \mathrm{H}_{2} \mathrm{O} \mathrm{m}^{-2} \mathrm{~s}^{-1}$, respectively. In phase II, $5^{\text {th }}$ day after irrigation cut-off, we observed mechanisms, such as leaf-rolling and stomatal closure. These events soften the solar radiation incidence and transpiration rate, respectively, increasing water conservation and delaying water deficit. Low values of $A, E$ and gs were observed in both years of trials. In 2015, $A$ ranged from 1.27 to $15.67 \mu \mathrm{mol} \mathrm{CO} \mathrm{Cm}^{-2} \mathrm{~s}^{-1}, E$ ranged from 0.97 to $4.14 \mathrm{mmol} \mathrm{H}_{2} \mathrm{O} \mathrm{m}^{-2} \mathrm{~s}^{-1}$, and $g s$ ranged from 0.04 to 0.47 mol $\mathrm{H}_{2} \mathrm{O} \mathrm{m}^{-2} \mathrm{~s}^{-1}$. In 2017, $A$ ranged from 0.82 to 19.21 $\mu \mathrm{mol} \mathrm{CO}_{2} \mathrm{~m}^{-2} \mathrm{~s}^{-1}, E$ ranged from 1.07 to $6.27 \mathrm{mmol}$ $\mathrm{H}_{2} \mathrm{O} \mathrm{m}^{-2} \mathrm{~s}^{-1}$, and gs ranged from 0.02 to $0.14 \mathrm{~mol} \mathrm{H}_{2} \mathrm{O}$ $\mathrm{m}^{-2} \mathrm{~s}^{-1}$. Four out of five top genotypes (Bico Ganga, BRS Esmeralda, BRSMG Curinga, and Rabo de Burrol showed average reduction of $84 \%, 72 \%$, and $81 \%$ in $A, E$, and $g s$, respectively, in plants cultivated under drought. In phase III, after plants under stress received $50 \%$ of water at the column base for 10 days, only three genotypes, Três Meses Branco (2015), Branquinho 90 Dias, and Rabo de Burro (2017) restored the functioning of the photosynthetic machinery, since stressed plants showed values of photosynthetic rate similar to those of irrigated plants. Conversely, for the other genotypes including Bico Ganga, BRS Esmeralda, BRSMG Curinga, and Guarani (top genotypes), recovery of $A, E$, and $g_{s}$ was $40 \%, 46 \%$, and $30 \%$, respectively, in stressed plants.

When water deficits start to increase, leaf stomatal conductance usually decreases faster than carbon assimilation, leading to increased WUE. The WUE reflects the multiple environmental stimuli perceived and the capacity of a particular genotype to sense the onset of changes in moisture availability and therefore to fine-tune its water status in response to the environment (Wilkinson, 2004; Blankenagel et al., 2018).

However, despite the negative impact of water deficit on gas exchange, in both years of trials, Bico Ganga, BRS Esmeralda, BRSMG Curinga, and Guarani (top genotypes) improved their WUE (44 \%) when compared with optimal irrigation conditions. This was most probably due to higher stomatal control efficiency, keeping approximately $40 \%$ of the photosynthetic process and drastically reducing stomatal conductance $(70 \%)$ by closing the stomata process. Although Rabo de Burro did not show increase in $W U E$, it presented a recovery of the gas exchange apparatus compared to irrigated plants, which can be justified partly by its vigorous root system.

In addition to increased relative stomatal limitation, drought stress is responsible for reducing maximum Rubisco carboxylation activity and electron transport and therefore ribulose bisphosphate (RuBP) regeneration (Perdomo et al., 2017). The carboxylation efficiency could be considered an estimate of the Rubisco activity, illustrating its limitations under stress conditions 
(Niinemets et al., 2009). In our study, all upland rice genotypes showed a poor capacity to overcome limitation in $\mathrm{CO}_{2}$ diffusion by stomata and mesophyll and effective $\mathrm{CO}_{2}$ fixation (70\% of CE reduction) during phase II for both years of trials. After replenishing $50 \%$ of water at the column base for 10 days, recovery of $55 \%$ and 64 $\%$ in the carboxylation efficiency was observed in 2015 and 2017, respectively. Considerable loss of Rubisco activity during stress conditions were also reported for sugarcane subjected to water deficit (Saliendra et al., 1996; Vu and Allen Jr., 2009). Overall, a response pattern was not observed among genotypes with greater yield performance under water deficit, since they showed divergent physiological responses of gas exchange.

Furthermore, remobilization of photoassimilates from vegetative into reproductive structures may have a significant effect on grain yield, although this component was not evaluated in our study. As demonstrated for cereals (Blum et al., 1994) and legumes (Chaves et al., 2002), nutrient pre-anthesis reserves are used for grain filling in addition to current assimilates. In rice, droughtinduced leaf senescence also promotes assimilate allocation to grains under development, shortening grain filling and increasing the grain filling rate (Sehgal et al., 2018). Moreover, senescence and reserve mobilization are integral components of plant development and basic strategies in stress mitigation (Lemoine et al., 2013).

Water stress effects on $\Psi \mathrm{w}, \mathrm{RWC}, \Psi \mathrm{s}$, and $\mathrm{OA}$, evaluated only in the 2015 trial, are shown in Table 6. Among top genotypes, BRS Esmeralda, BRSMG Curinga, Guarani, and Rabo de Burro showed a more pronounced gradient of $\psi_{\mathrm{w}}$ and probably enhanced water absorption capacity. Besides, advance of the most severe internal damage may have reduced in the reproductive organs under the drought period. Conversely, Bico Ganga kept high water potential during the water deficit period, which may be associated to a more robust root system in the second soil layer and thus higher panicle water potential, which probably contributes to increased grain yield. According to Guimarães et al. (2016), plants that prevent dehydration presented higher water potential and earliness in flowering, lower height, lower leaf area or lower tillering. Regarding the trait RWC, which is directly related to the plant water status, values ranged from $\sim 82 \%$ in leaves under irrigated condition to $75 \%$ for stressed plants. On the other hand, BRSMG Curinga

Table 6 - Water potential ( $\Psi$ w, MPa), osmotic potential ( $\Psi \mathrm{s}, \mathrm{MPa}$ ), relative water content (RWC, \%), and osmotic adjustment (OA; MPa) of upland rice (Oryza sativa L.) grown under irrigated and drought conditions. Trial in 2015.

\begin{tabular}{|c|c|c|c|c|c|c|c|c|}
\hline \multirow{3}{*}{ Genotypes } & \multicolumn{8}{|c|}{ Water level } \\
\hline & \multicolumn{4}{|c|}{ Irrigated } & \multicolumn{4}{|c|}{ Stressed } \\
\hline & $\Psi_{w}$ & $\Psi_{\mathrm{s}}$ & RWC & $\mathrm{OA}$ & $\Psi_{w}$ & $\Psi_{\mathrm{s}}$ & RWC & $\mathrm{OA}$ \\
\hline Agulhão & $-0.39 \mathrm{Aa}$ & $-1.235 \mathrm{Ba}$ & $81.73 \mathrm{Ba}$ & $0.000 \mathrm{Aa}$ & $-0.95 \mathrm{Ab}$ & $-1.272 \mathrm{Ca}$ & $70.09 \mathrm{Bb}$ & $0.037 \mathrm{Ea}$ \\
\hline Aimoré & $-0.16 \mathrm{Ba}$ & $-0.939 \mathrm{Ea}$ & $80.65 \mathrm{Ba}$ & $0.000 \mathrm{Aa}$ & $-0.53 \mathrm{Ba}$ & $-1.062 \mathrm{Da}$ & $76.64 \mathrm{Aa}$ & $0.122 \mathrm{Db}$ \\
\hline Amarelão & $-0.28 \mathrm{Aa}$ & $-1.080 \mathrm{Da}$ & $79.67 \mathrm{Ba}$ & $0.000 \mathrm{Aa}$ & $-0.36 \mathrm{Ba}$ & $-1.210 \mathrm{Cb}$ & $68.55 \mathrm{Bb}$ & $0.130 \mathrm{Db}$ \\
\hline Arroz 4 meses & $-0.03 \mathrm{Ba}$ & $-1.079 \mathrm{Da}$ & $81.19 \mathrm{Ba}$ & $0.000 \mathrm{Aa}$ & $-0.90 \mathrm{Ab}$ & $-1.132 \mathrm{Aa}$ & $70.03 \mathrm{Bb}$ & $0.050 \mathrm{Ea}$ \\
\hline Arroz Carolino & $-0.02 \mathrm{Ba}$ & $-0.987 \mathrm{Ea}$ & $79.34 \mathrm{Ba}$ & $0.000 \mathrm{Aa}$ & $-0.55 \mathrm{Bb}$ & $-1.205 \mathrm{Cb}$ & $75.62 \mathrm{Aa}$ & $0.217 \mathrm{Bb}$ \\
\hline Bico Ganga & $-0.20 \mathrm{Ba}$ & $-1.053 \mathrm{Da}$ & $76.19 \mathrm{Ba}$ & $0.000 \mathrm{Aa}$ & $-0.38 \mathrm{Ba}$ & $-1.255 \mathrm{Cb}$ & $73.98 \mathrm{Ba}$ & $0.202 \mathrm{Bb}$ \\
\hline Branquinho 90 Dias & $-0.03 \mathrm{Ba}$ & $-0.940 \mathrm{Ea}$ & $84.57 \mathrm{Ba}$ & $0.000 \mathrm{Aa}$ & $-0.39 \mathrm{Ba}$ & $-1.206 \mathrm{Cb}$ & $76.99 \mathrm{Ab}$ & $0.266 \mathrm{Ab}$ \\
\hline BRS Esmeralda & $-0.02 \mathrm{Ba}$ & $-1.250 \mathrm{Ba}$ & $83.21 \mathrm{Ba}$ & $0.000 \mathrm{Aa}$ & $-1.12 \mathrm{Ab}$ & $-1.495 \mathrm{Ab}$ & $79.36 \mathrm{Aa}$ & $0.245 \mathrm{Ab}$ \\
\hline BRS Primavera & $-0.24 \mathrm{Aa}$ & $-1.141 \mathrm{Ca}$ & $86.35 \mathrm{Ba}$ & $0.000 \mathrm{Aa}$ & $-0.48 \mathrm{Ba}$ & $-1.399 \mathrm{Ab}$ & $83.78 \mathrm{Aa}$ & $0.258 \mathrm{Ab}$ \\
\hline BRS Serra Dourada & $-0.33 \mathrm{Aa}$ & $-1.138 \mathrm{Ca}$ & $79.42 \mathrm{Ba}$ & $0.000 \mathrm{Aa}$ & $-0.38 \mathrm{Ba}$ & $-1.267 \mathrm{Cb}$ & $77.56 \mathrm{Aa}$ & $0.129 \mathrm{Db}$ \\
\hline BRS Soberana & $-0.35 \mathrm{Aa}$ & $-1.115 \mathrm{Ca}$ & $76.12 \mathrm{Ba}$ & $0.000 \mathrm{Aa}$ & $-0.36 \mathrm{Ba}$ & $-1.165 \mathrm{Ca}$ & $66.89 \mathrm{Bb}$ & $0.116 \mathrm{Db}$ \\
\hline BRSMG Curinga & $-0.12 \mathrm{Ba}$ & $-1.218 \mathrm{Ba}$ & $83.04 \mathrm{Ba}$ & $0.000 \mathrm{Aa}$ & $-0.93 \mathrm{Ab}$ & $-1.235 \mathrm{Ca}$ & $73.81 \mathrm{Bb}$ & $0.022 \mathrm{Ea}$ \\
\hline Carajás & $-0.03 \mathrm{Ba}$ & $-0.995 \mathrm{Da}$ & $79.01 \mathrm{Ba}$ & $0.000 \mathrm{Aa}$ & $-0.40 \mathrm{Ba}$ & $-1.216 \mathrm{Cb}$ & $72.64 \mathrm{Ba}$ & $0.221 \mathrm{Bb}$ \\
\hline Casca Branca & $-0.03 \mathrm{Ba}$ & $-1.403 \mathrm{Aa}$ & $96.72 \mathrm{Aa}$ & $0.000 \mathrm{Aa}$ & $-0.49 \mathrm{Bb}$ & $-1.446 \mathrm{Aa}$ & $76.48 \mathrm{Ab}$ & $0.043 \mathrm{~Eb}$ \\
\hline Cirad 392 & $-0.02 \mathrm{Ba}$ & $-1.057 \mathrm{Da}$ & $76.17 \mathrm{Ba}$ & $0.000 \mathrm{Aa}$ & $-0.39 \mathrm{Ba}$ & $-1.172 \mathrm{Ca}$ & $72.22 \mathrm{Ba}$ & $0.114 \mathrm{Db}$ \\
\hline Comum & $-0.04 \mathrm{Ba}$ & $-1.522 \mathrm{Ab}$ & $77.94 \mathrm{Ba}$ & $0.000 \mathrm{Aa}$ & $-0.51 \mathrm{CB}$ & $-1.783 \mathrm{Aa}$ & $69.88 \mathrm{Bb}$ & $0.051 \mathrm{Ea}$ \\
\hline Douradão & $-0.45 \mathrm{Aa}$ & $-1.130 \mathrm{Ca}$ & $83.08 \mathrm{Ba}$ & $0.000 \mathrm{Aa}$ & $-0.71 \mathrm{Ba}$ & $-1.142 \mathrm{Da}$ & $78.11 \mathrm{Aa}$ & $0.012 \mathrm{~Eb}$ \\
\hline Guarani & $-0.03 \mathrm{Ba}$ & $-1.163 \mathrm{Ca}$ & $81.59 \mathrm{Ba}$ & $0.000 \mathrm{Aa}$ & $-0.43 \mathrm{Bb}$ & $-1.318 \mathrm{Bb}$ & $79.39 \mathrm{Aa}$ & $0.155 \mathrm{Cb}$ \\
\hline IRAT 112 & $-0.04 \mathrm{Ba}$ & $-0.916 \mathrm{Ea}$ & $80.78 \mathrm{Ba}$ & $0.000 \mathrm{Aa}$ & $-0.50 \mathrm{Bb}$ & $-1.017 \mathrm{Da}$ & $71.00 \mathrm{Bb}$ & $0.101 \mathrm{Db}$ \\
\hline Moroberekan & $-0.12 \mathrm{Ba}$ & $-1.259 \mathrm{Ba}$ & $83.83 \mathrm{Ba}$ & $0.000 \mathrm{Aa}$ & $-1.44 \mathrm{Ab}$ & $-1.325 \mathrm{Ba}$ & $75.88 \mathrm{Ab}$ & $0.035 \mathrm{Ea}$ \\
\hline Rabo de Burro & $-0.46 \mathrm{Aa}$ & $-1.212 \mathrm{Ba}$ & $82.30 \mathrm{Ba}$ & $0.000 \mathrm{Aa}$ & $-1.33 \mathrm{Ab}$ & $-1.228 \mathrm{Ca}$ & $81.19 \mathrm{Aa}$ & $0.016 \mathrm{Ea}$ \\
\hline Rio Doce & $-0.04 \mathrm{Ba}$ & $-1.080 \mathrm{Da}$ & $79.49 \mathrm{Ba}$ & $0.000 \mathrm{Aa}$ & $-0.63 \mathrm{Bb}$ & $-1.321 \mathrm{Bb}$ & $74.35 \mathrm{Ba}$ & $0.241 \mathrm{Ab}$ \\
\hline Saia Velha & $-0.51 \mathrm{Aa}$ & $-1.065 \mathrm{Da}$ & $79.35 \mathrm{Ba}$ & $0.000 \mathrm{Aa}$ & $-1.23 \mathrm{Ab}$ & $-1.178 \mathrm{Ca}$ & $70.34 \mathrm{Bb}$ & $0.113 \mathrm{Db}$ \\
\hline Tangará & $-0.40 \mathrm{Aa}$ & $-0.988 \mathrm{Ea}$ & $70.98 \mathrm{Ba}$ & $0.000 \mathrm{Aa}$ & $-0.42 \mathrm{Ba}$ & $-1.146 \mathrm{Db}$ & $70.69 \mathrm{Ba}$ & $0.160 \mathrm{Cb}$ \\
\hline Três Meses Branco & $-0.28 \mathrm{Aa}$ & $-0.918 \mathrm{Ea}$ & $79.71 \mathrm{Ba}$ & $0.000 \mathrm{Aa}$ & $-0.73 \mathrm{Bb}$ & $-1.115 \mathrm{Cb}$ & $73.69 \mathrm{Ba}$ & $0.316 \mathrm{Ab}$ \\
\hline
\end{tabular}

Capital letters compare genotypes within each water regime and small letters compare water regimes within each genotype. Means followed by the same capital letter in the column and means followed by the same letter on the rows do not differ by the Scott-Knott test $5 \%$ error probability. Transformed data in square root of $\mathrm{Y}+1.0-\mathrm{SQRT}(\mathrm{Y}+1.0)$ for the statistical analysis. 
presented significant RWC reduction due to the stress imposed. This divergent responses regarding leaf water status suggest greater capacity of top genotypes to save water during drought and stimulate an adjustment of the photosynthetic capacity to tolerate changes in water availability (Silva et al., 2007; Rodrigues et al., 2009; Graça et al., 2010). The mechanism of osmotic adjustment (OA), usually accomplished by accumulation of compatible solutes ( $\psi s)$ and maintenance of RWC, although significant for all genotypes, was numerically higher for BRS Esmeralda, followed by Bico Ganga and Guarani, compared to BRSMG Curinga and Rabo de Burro (top genotypes). This mechanism in upland rice plants during the reproductive phase allows maintenance of adequate physiological state, in which the leaves remain green and cool for a longer time, besides allowing the establishment and retention of spikelet and, consequently, grain yield sustenance (Fischer et al., 2003).

This study describes important aspects of droughtinduced effect on upland rice, providing a better understanding of morphophysiological changes under water deficit. Top genotypes showed distinct strategies by activating different physiological responses: higher ability to save water on leaves (Bico Ganga, BRS Esmeralda, BRSMG Curinga and Rabo de Burrol, lower leaf water potential (Bico Ganga, BRS Esmeralda, BRSMG Curinga and Guarani), higher ability to reduce vegetative structures (Bico Ganga, BRSMG Curinga and Rabo de Burro), higher efficiency in the use of water (Bico Ganga, BRS Esmeralda, BRSMG Curinga and Guarani), higher photosynthetic capacity (Guarani), and improved ability to absorb water from drying soil, either by osmotic adjustment (Bico Ganga, BRS Esmeralda and Guarani) or additional investment in the root system (BRSMG Curinga and Rabo de Burro). Therefore, different mechanisms, such as vegetative morphology, gas exchange, water status, and root system could be explored simultaneously to support the development of drought-tolerant rice cultivars by breeding programs.

\section{Authors' Contributions}

Conceptualization: Vianello, R.P.; Lanna, A.C.; Brondani, C. Data analysis: Lanna, A.C.; Coelho, G.R.C.; Moreira, A.S.; Terra, T.G.R. Data acquisition: Lanna, A.C.; Coelho, G.R.C.; Saraiva, G.R.; Lemos, F.S. Design of methodology: Lanna, A.C.; Guimarães, P.H.R.; Morais Júnior, O.P. Writing and editing: Lanna, A.C.; Moreira, A.S.; Brondani, C.; Vianello, R.P.

\section{References}

Bajji, M.; Lutts, S.; Kinet, J-M. 2001. Water deficit effects on solute contribution to osmotic adjustment as a function of leaf ageing in three durum wheat (Triticum durum Desf.) cultivars performing differently in arid conditions. Plant Science 160: 669-681.
Blankenagel, S.; Yang, Z.; Avramova, V.; Schon, C-C.; Grill, E. 2018. Generating plants with improved water use efficiency. Agronomy 8: 194.

Bernier, J.; Atlin, G.N.; Serraj, R.; Kumar, A.; Spaner, D. 2008. Breeding upland rice for drought resistance. Journal of Science of Food and Agriculture 88: 927-939.

Blum, A.; Sinmena, B.; Mayer, J.; Golan, G.; Shpiler, L. 1994. Stem reserve mobilization supports wheat-grain filling under heat stress. Australian Journal of Plant Physiology 21: 771-781.

Boonjung, H.; Fukai, S. 1996. Effects of soil water deficit at different growth stages on rice growth and yield under upland conditions. 2. Phenology, biomass production and yield. Field Crops Research 48: 47-55.

Bueno, L.G.; Vianello, R.P.; Rangel, P.H.N.; Utumi, M.M.; Cordeiro, A.C.C.; Pereira, J.A.; Franco, D.F.; Moura Neto, F.; Mendonça, J.A.; Coelho, A.S.G.; Oliveira, J.P.; Brondani, C. 2012. Adaptability and stability approach of a nuclear rice collection. Pesquisa Agropecuária Brasileira 47: 216-226 (in Portuguese, with abstract in English).

Chaves, M.M.; Pereira, J.S.; Maroco, J.P.; Rodrigues, M.L.; Ricardo, C.P.P.; Osório, M.L.; Carvalho, I.; Faria, T.; Pinheiro, C. 2002. How plants cope with water stress in the field: photosynthesis and growth. Annals of Botany 89: 907-916.

Chaves, M.M.; Maroco, J.P.; Pereira, J.S. 2003. Understanding plant response to drought: from genes to the whole plant. Functional Plant Biology 30: 239-264.

Chaves, M.M.; Flexa, J.; Pinheiro, C. 2009. Photosynthesis under drought and salt stress: regulation mechanisms from whole plant to cell. Annals of Botany 103: 551-560.

Choudhary, A.K.; Sultana, R.; Vales, M.I.; Saxena, K.B.; Kumar, R.R.; Ratnakumar, P. 2018. Integrated physiological and molecular approaches to improvment of abiotic stress tolerance in two pulse crops of the semi-arid tropics. The Crop Journal 6: 99-114.

Counce, P.A.; Keisling, T.C.; Mitchell, A.J. 2000. A uniform, objective, and adaptive system for expressing rice development. Crop Science 40: 436-443.

Fischer, K.S.; Lafitte, R.; Fukai, S.; Atlin, G.; Hardy, B. 2003. Breeding Rice for Drought-Prone Environments. International Rice Research Institute, Los Baños, Philippines.

Fukai, S.; Cooper, M. 1995. Development of drought-resistant cultivars using physio-morphological traits in rice. Field Crops Research 40: 67-86.

Graça, J.P.; Rodrigues, F.A.; Farias, J.R.B.; Oliveira, M.C.N.; Hoffmann-Campo, C.B.; Zingaretti, S.M. 2010. Physiological parameters in sugarcane cultivars submitted to water deficit. Brazilian Journal Plant Physiology 22: 189-197.

Guimarães, C.M.; Castro, A.P.; Stone, L.F.; Oliveira, J.P. 2016. Drought tolerance in upland rice: identification of genotypes and agronomic characteristics. Acta Scientiarum Agronomy 38: 201-206.

Heinemann, A.B.; Barrios-Perez, C.; Ramirez-Villegas, J.; ArangoLondoño, D.; Bonilla-Findji, O.; Medeiros, J.C.; Jarvis, A. 2015. Variation and impact of drought-stress patterns across upland rice target population of environments in Brazil. Journal of Experimental Botany 66: 3625-3638.

Ji, K.; Wang, Y.; Sun, W.; Lou, Q.; Mei, H.; Shen, S.; Chen, H. 2012. Drought-responsive mechanisms in rice genotypes with contrasting drought tolerance during reproductive stage. Journal of Plant Physiology 169: 336-344. 
Jumaa, S.H.; Redona, E.D.; Walker, T.; Gao, W.; Reddy, K.R. 2019. Developing screening tools for early-season high- and low-temperature stress tolerance in rice. SABRAO Journal of Breeding and Genetics 51: 12-36.

Kamoshita, A.; Rodriguez, R.; Yamauchi, A.; Wade, L.J. 2004. Genotypic variation in response of rainfed lowland rice to prolonged drought and dewatering. Plant Production Science 7: 406-420.

Kato, Y.; Abe, J.; Kamoshita, A.; Yamagishi, J. 2006. Genotypic variation in root growth angle in rice (Oryza sativa L.) and its association with deep root development in upland fields with different water regimes. Plant Soil 287: 117-129.

Kikuta, M.; Yamamotto, Y.; Pasolon, Y.B.; Rembon, F.S.; Miyazak, A.; Makihara, D. 2016. How growth and yield of upland rice vary with topographic conditions: a case of Slash-and-burn rice farming in South Konawe Regency, southeast Sulawesi Province, Indonesia. Tropical Agriculture and Development 60: 12-171.

Kundur, P.; Ashwathanarayana, R.; Keerthi, C.M.; Brijesh, A.; Shashidhar, H.E. 2015. Genotypic variation for root growth orientation in rice (Orysa sativa L.) under aerobic and well-watered condition. International Journal of Current Research 7: 16331-16336.

Lanna, A.C.; Mitsuzono, S.T.; Terra, T.G.R.; Vianello, R.P.; Carvalho, M.A.F. 2016. Physiological characterization of common bean (Phaseolus vulgaris L.) genotypes waterstress, induced with contrasting response towards drought. Australian Journal of Crop Science 10: 1-6.

Lemoine, R.; La Camera, S.; Atanassova, R.; Déaldéchamp, F.; Allario, T.; Pourtau, N.; Bonnemain, J-L.; Laloi, M.; CoutosThévenot, P.; Maurousset, L.; Faucher, M.; Girousse, C.; Lemonnier, P.; Parrilla, J.; Durand, M. 2013. Source-to-sink transport of sugar and regulation by environmental factors. Frontiers in Plant Science 4: 1-21.

Ma, X.; He, Q.; Zhou, G. 2018. Sequence of changes in maize responding to soil water deficit and related critical thresholds. Frontiers in Plant Science 9: 511-522.

Matsui, T.; Namuco, O.S.; Ziska, L.H.; Horie, T. 1997. Effects of high temperature and $\mathrm{CO}_{2}$ concentration on spikelet sterility in indica rice. Field Crops Research 51: 213-219.

Mishra, A.; Salokhe, V.M. 2011. Rice root growth and physiological responses to SRI water management and implications for crop productivity. Paddy Water Environment 9: 41-52.

Niinemets, U.; Díaz-Espejo, A.; Flexas, J.; Galmés, J.; Warren, C.R. 2009. Importance of mesophyll diffusion conductance in estimation of plant photosynthesis in the field. Journal of Experimental Botany 60: 2271-2282.

Pandey, V.; Shukla, A. 2015. Acclimation and tolerance strategies of rice under drought stress. Rice Science 22: 147161.

Parthasarathi, T.; Vanitha, K.; Lakshamanakumar, P.; Kalaiyarasi, F. 2012. Aerobic rice-mitigating water stress for the future climate change. International Journal of Agronomy and Plant Production 3: 241-254.

Peng, S.; Ingram, K.T.; Neue, H.U.; Ziska, L.H. 1995. Climate Change and Rice. Springer, Berlin, Germany.
Perdomo, J.A.; Capó-Bauçà, S.; Carmo-Silva, E.; Galmés, J. 2017. Rubisco and Rubisco Activase play an important role in the biochemical limitations of photosynthesis in rice, wheat, and maize under high temperature and water deficit. Frontiers in Plant Science 8: 1-15.

Rodrigues, F.A.; Laia, M.L.; Zingaretti, S.M. 2009. Analysis of gene expression profiles under water stress in tolerant and sensitive sugarcane plants. Plant Science 176: 286-302.

Rosales, M.A.; Ocampo, E.; Rodriguez-Valentin, R.; OlveraCarrillo, Y.; Acosta-Gallegos, J.; Covarrubias, A.A. 2012. Physiological analysis of common bean (Phaseolus vulgaris L.) cultivars uncovers characteristics related to terminal drought resistance. Plant Physiology and Biochemistry 56: 24-34.

Saliendra, N.Z.; Meinzer, F.C.; Perry, M.; Thom, M. 1996. Associations between partitioning of carboxylase activity and bundle sheath leakiness to $\mathrm{CO}_{2}$, carbon isotope discrimination, photosynthesis, and growth in sugarcane. Journal of Experimental Botany 47: 907-914.

Scholander, P.F.; Hammel, H.T.; Brandstreet, E.D.; Hemmingsen, E.A. 1965. Sap pressure in vascular plants. Science 148: 339346.

Sehgal, A.; Sita, K.; Siddique, K.H.M.; Kimar, R.; Bhogireddy, S.; Varshney, R.K.; HanumanthaRao, B.; Nair, R.; Vara Prasad, P.V.; Nayyar, H. 2018. Drought or/and heat-stress effects on seed filling in food crops: impacts on functional biochemistry, seed yields, and nutritional quality. Frontiers in Plant Science 9: 1-19.

Shah, F.; Huang, J.; Lui, K.; Nie, L.; Shah, T.; Chen, C.; Wang, K. 2011. Impact of high-temperature stress on rice plant and its traits related to tolerance. Journal of Agricultural Science 149: 545- 556.

Shapiro, S.S.; Wilk, M.B. 1965. An analysis of variance test for normality (complete sample). Biometrika 52: 91-611.

Silva, M.A.; Jifon, J.L.; Silva, J.A.G.; Sharma, V. 2007. Use of physiological parameters as fast tools to screen for drought tolerance in sugarcane. Brazilian Journal of Plant Physiology 19: 193-201.

Silva, M.A.; Jifon, J.L.; Santos, C.M.; Jadoski, C.J.; Silva, J.A.G. 2013. Photosynthetic capacity and water use efficiency in sugarcane genotypes subject to water deficit during early growth phase. Brazilian Archives of Biology and Technology 56: 735-748.

Singh, A.; Singh, A.K.; Singh, V.; Singh, N.; Singh, V.N.; Shamim, M.; Vikram, P.; Singh, S. 2014. Genetic variability among traits associated with grain yield of rice (Oryza sativa L.) exposed to drought at flowering stage. African Journal of Agricultural Research 9: 1252-1264.

Vu, J.C.V.; Allen Jr., L. 2009. Growth at elevated $\mathrm{CO}_{2}$ delays the adverse effects of drought stress on leaf photosynthesis of the C4 sugarcane. Journal of Plant Physiology 166: 107-116.

Wilkinson, S. 2004. Water use efficiency and chemical signaling. Chapter 4. In: Bacon, M., ed. Water use efficiency in plant biology. Blackwell, London, England.

Wu, W.; Cheng, S. 2014. Root genetic research, an opportunity and challenge to rice improvement. Field Crops Research 165: 111-124.

Zhu, J.K. 2002. Salt and drought stress signal transduction in plants. Annual Review of Plant Biology 53: 247-273. 